\title{
A Combination of Two Receptor Tyrosine Kinase Inhibitors, Canertinib and PHA665752 Compromises Ovarian Cancer Cell Growth in 3D Cell Models
}

\author{
Wafaa Hassan · Kenny Chitcholtan · Peter Sykes · Ashley Garrill
}

Received: July 12, 2016 / Published online: September 27, 2016

(C) The Author(s) 2016. This article is published with open access at Springerlink.com

\section{ABSTRACT}

Introduction: Advanced ovarian cancer is often a fatal disease as chemotherapeutic drugs have limited effectiveness. Better targeted therapy is needed to improve the survival and quality of life for these women. Receptor tyrosine kinases including EGFR, Her-2 and c-Met are associated with a poor prognosis in ovarian cancer. Therefore, the co-activation of these receptors may be crucial for growth promoting activity. In this study, we explored the effect of combining two small molecule inhibitors that target the EGFR/Her-2 and c-Met receptor tyrosine kinases in two ovarian cancer cell lines. The aim of this study was to investigate the combined inhibition activity of a dual

Enhanced content To view enhanced content for this article go to http://www.medengine.com/Redeem/ EE76F06032E5AE54\#/EsmModal.

W. Hassan · A. Garrill

School of Biological Sciences, University of Canterbury, Private Bag, 4800 Christchurch, New Zealand

K. Chitcholtan $(\bowtie) \cdot$ P. Sykes

Department of Obstetrics and Gynaecology, University of Otago, Christchurch Women's Hospital, 2 Riccarton Avenue, Christchurch, New Zealand

e-mail: kenny.chitcholtan@otago.ac.nz
EGFR/Her-2 inhibitor (canertinib) and a c-Met inhibitor (PHA665752) in ovarian cancer cell lines in 3D cell aggregates.

Methods: OVCAR-5 and SKOV-3 ovarian cancer cell lines were cultured on a non-adherent surface to produce 3D cell clusters and aggregates. Cells were exposed to canertinib and PHA665752, both individually and in combination, for $48 \mathrm{~h}$. The effect on growth, metabolism and the expression/ phosphorylation of selective signaling proteins associated with EGFR, Her-2 and c-Met were investigated.

Results: The single drug treatments significantly decreased cell growth and altered the expression of signaling proteins in OVCAR-5 and SKOV-3 cell lines. The combination treatment showed greater reduction of cell numbers for both cell lines. Total expression and phosphorylation of signaling proteins were further reduced in the combination drug treatments, compared to the single inhibitor treatments.

Conclusion: Our findings suggest that the concurrent targeting of more than one receptor tyrosine kinase may be useful in developing more effective targeted drug 
regimens for patients, who have EGFR, Her-2 and c-Met positive ovarian cancer cells.

Keywords: Canertinib; c-MET; Cell clusters; EGFR; Ovarian cancer; PHA665752; Tyrosine kinase inhibitors

\section{INTRODUCTION}

Ovarian cancer is the leading cause of death from gynecological cancers in developed countries. The majority of ovarian cancer patients are diagnosed with an advanced stage of the disease, and as such they typically have a 5-year survival rate lower than 30\% [1]. For the majority of women, cytotoxic chemotherapeutics have limited efficacy. Therefore, there is an urgent need for alternative anticancer agents that have the potential to control tumor growth, improve the quality of life, and increase the longevity of patients.

A number of targeted anticancer drugs have been studied; among these drugs are small molecule inhibitors of receptor tyrosine kinases. A subset of cancer cells is dependent on the over activation of epidermal growth factor receptor proteins including EGFR and Her-2. Therefore, an inhibitor that specifically blocks these receptors may have clinical activity. Specific inhibitors of EGFR and Her-2 including gefitinib, erlotinib, lapatinib, and a monoclonal antibody Herceptin have been approved by the FDA to treat different types of cancers that include breast cancer, colon cancer and non-small cell lung cancer, NSCLC $[2,3]$. The EGFR and Her-2 inhibitors as a monotherapy show minimal clinical benefit in ovarian cancer trails $[4,5]$. The lack of clinical efficacy of these inhibitors is perhaps due to activation of multiple receptor tyrosine kinases and the activation of several down stream signaling proteins. In this study, we explore the possibility that targeting of multiple receptor tyrosine kinases will lead to greater effects on tumor growth potential.

Some advanced ovarian cancer cells have been shown to possess high levels of the receptors EGFR and Her-2 [6]. It is the activation of these receptors that may promote the growth of malignant cells, and the over expression of these receptors has been associated with a poor prognosis and invasive phenotypic changes $[7,8]$. There is evidence to suggest that EGFR/Her-2 expressing malignant cells may not be sensitive to the EGFFR and Her-2 inhibitors as ovarian cancer cells are able to use alternate a receptor tyrosine kinase for growth promotion [9]. The c-Met is also a receptor tyrosine kinase, which has elevated levels in ovarian cancer cells [10]. The c-Met receptors are activated when they are bound by the hepatocyte growth factor, HGF, which is elevated in the ascitic fluid of women with advanced stages of ovarian cancer [11]. The EGFR, Her-2 and c-Met receptors share common downstream signaling molecules that can promote cell survival, motility, and invasion and cross-communication between these three receptors may promote cancer progression and resistance to therapy [12]. Thus, c-Met could be an additional potential target for cancer treatment and raises the strategic possibility of combined targets of receptor tyrosine kinases concurrently.

Candidate molecules for such combined strategies are canertinib and PHA665752. Canertinib, also known as CI-1033, is an irreversible inhibitor of receptor tyrosine kinases, binding to the ATP-binding site. It has shown potent effects against several cancer cell lines targeting EGFR and Her-2. Clinical trials of canertinib have been conducted against a number of tumor types, including breast 
cancer [13], NSCLC [3], and advanced ovarian cancer [5]. However, canertinib alone showed modest activities in clinical studies with ovarian cancer patients [5]. PHA665752 is a reversible inhibitor of c-Met, which at nano-molar concentrations has shown in vivo anti-tumor activity [14].

Advanced ovarian cancer patients often have ascitic fluid in the abdominal cavity. In the fluid, ovarian malignant cells form 3D structures; these microscopic clusters and aggregates are a major source of secondary growth potential $[15,16]$. These clusters and aggregates then deposit on the peritoneal lining and the surface of internal organs to continue their growth. Therefore, it is appropriate to use cell clusters and aggregates as an in vitro cell model to replicate the behavior of ovarian cancer cells. We hypothesized that floating cell clusters and aggregates ovarian cancer cells may use the concurrent activation of EGFR, Her-2 and c-Met to sustain growth and cell survival. Combined inhibition of these receptors will produce a greater anti-growth effect in ovarian cancer cells. The aim of the present study was to test the effect of such combined inhibitors on $3 \mathrm{D}$ cell cultures of two ovarian cancer cell lines, OVCAR-5- and SKOV-3.

\section{METHODS}

The human ovarian adenocarcinoma cell lines, OVCAR-5 and SKOV-3 were used. Both cell lines were obtained from Dr. Judith Mckenzie, Haematology Research group, University of Otago, Christchurch, New Zealand. OVCAR-5 and SKOV-3 cells were maintained in DMEM/ F12 or MEM media $\left(\mathrm{GIBCO}^{\circledR}\right.$, Life Technologies, New Zealand), respectively, both supplemented with $5 \%$ fetal bovine serum (FBS) $\left(\mathrm{GIBCO}^{\circledR}\right.$, Life Technologies, New Zealand), PenStrep $\left(\right.$ GIBCO $^{\circledR}$, Life Technologies, New Zealand) at a working concentration of 100 units $/ \mathrm{ml}$ penicillin, $100 \mu \mathrm{g} / \mathrm{ml}$ streptomycin, $2 \mathrm{mM}$ glutaMAX $^{\mathrm{TM}}\left(\mathrm{GIBCO}^{\circledR}\right.$, Life Technologies, New Zealand), and $2 \mu \mathrm{g} / \mathrm{ml}$ Fungizone ${ }^{\circledR} \quad$ (Life Technologies, New Zealand). The final concentration of glucose in the media was $5.5 \mathrm{mM}$. The respective supplemented media is henceforth referred to as working media. Cells were maintained at $37{ }^{\circ} \mathrm{C}$ in a humidified $5 \%$ $\mathrm{CO}_{2}$ atmosphere. This article does not contain any studies with human or animal subjects performed by any of the authors.

\section{Generation of 3D Cell Aggregates}

Twelve or twenty-four welled culture plates were coated with $24 \mathrm{mg} / \mathrm{ml}$ poly (2-hydroxyethylmethacrylate) (poly-HEMA) (Sigma, New Zealand), a polymer that prevents cells from adhering to the surface of culture wells. The poly-HEMA was dissolved in $95 \%$ ethanol and heated to approximately $70{ }^{\circ} \mathrm{C}$ until completely dissolved. The cell culture plates were coated with $300 \mu \mathrm{L}$ poly-HEMA solution and placed overnight on an orbital shaker at $37^{\circ} \mathrm{C}$ and then left to cool down prior the cell culture. Plates were washed with PBS $\mathrm{pH}$ 7.4. Cell monolayers were incubated with diluted $1 \times$ Trypsin-EDTA (Thermo Fisher Scientific, New Zealand) for 20-30 min to detach cells from the flask. Cell numbers were determined with a hemocytometer to ensure that each well contained approximately 100,000 cells with a total volume of $1 \mathrm{ml}$ working media. Cells were then incubated at $37^{\circ} \mathrm{C}$ in a humidified $5 \% \mathrm{CO}_{2}$ atmosphere for 6 days to obtain cellular aggregates. Media were removed and replaced with $1 \mathrm{ml}$ of fresh media every second day. 
Treatments with Canertinib and PHA665752, HGF and EGF

Canertinib (CI-1033) was purchased from LC laboratories (Massachusetts, USA) and PHA665752 was obtained from Sigma (Auckland, New Zealand). Both compounds were dissolved in 100\% DMSO. Final DMSO volumes were normalized for all experiments and were less than $0.5 \%(\mathrm{v} / \mathrm{v})$. Cells were then synchronized in media without FBS for $24 \mathrm{~h}$, before they were exposed to the inhibitors and growth factors. Cells were activated with HGF and EGF $\left(\right.$ GIBCO $^{\circledR}$, Life Technologies, New Zealand) during drug treatment. Fresh working media containing combined growth factors at concentrations of 0.2 and $20 \mathrm{ng} / \mathrm{ml}$ were used to activate cellular activity. In our dose-dependent stimulation of a single inhibitor, we used a range of $(2-4 \mu \mathrm{M})$ canertinib and $(0.5-2.0 \mu \mathrm{M})$ PHA665752.

For the combined treatments, cells were treated with both canertinib $(3 \mu \mathrm{M})$ and PHA665752 $(1 \mu \mathrm{M}$ for $24 \mathrm{~h}$. After the first $24 \mathrm{~h}$, PHA665752 was re-added to the combination-treated cells, and cells were incubated for a further $24 \mathrm{~h}$ before harvesting. At least three independent experiments were carried out and each individual experiment was carried out in triplicates.

\section{Analysis of Morphology and Cell Viability of Cells in Clusters and Aggregates}

After culturing for 6 days, cell aggregates of both cell lines were imaged using an inverted light microscope equipped with a digital camera, using a $10 \times / 0.25$ N.A. objective lens (ACCU-SCOPE ${ }^{\circledR}$ 3032). After treatment periods, cells in clusters and aggregates were harvested and digested with $1 \times$ trypsin-EDTA to obtain single cell suspensions, and cells were counted using a hemocytometer to assess cell viability.

\section{Immunofluorescent Detection of Receptors}

For immunofluorescent imaging, OVCAR-5 and SKOV-3 cells were cultured for 6 days to generate cell clusters and aggregates. The media were refreshed every second day. Cell clusters and aggregates were harvested and fixed with ice-cold 50\% (v/v) acetone/methanol solution. OVCAR-5 cell clusters were washed twice with ice-cold PBS, pH 7.4 and re-suspended in $200 \mu \mathrm{l}$ cold PBS. Clusters were then mounted on poly-lysine coated microscope slides and left to dry at $37^{\circ} \mathrm{C}$. Once cells were dry, cells were blocked with $4 \%$ BSA in PBS. Cells were stained overnight with a 1:200 dilution of primary antibody at $4{ }^{\circ} \mathrm{C}$. Cells were then washed with ice-cold PBS pH 7.4. A 1:500 dilution of secondary antibody, conjugated with FITC was added to cells and further incubated for $60 \mathrm{~min}$. The secondary antibody solution was removed and $500 \mu \mathrm{l}$ of $10 \mu \mathrm{g} / \mathrm{ml}$ DAPI was added to the cells and left for $20 \mathrm{~min}$ in the dark. Cells were then washed with $0.1 \%$ Tween-20 in PBS pH 7.4 and were mounted in ice-cold anti-fading solution $(2 \mathrm{mg} /$ $\mathrm{ml} p$-phenylenediamine in $80 \%$ glycerol, $\mathrm{pH}$ 7.8).

SKOV-3 aggregates were washed with PBS $\mathrm{pH}$ 7.4 and stained with aniline blue dye for $20 \mathrm{~min}$. Cells were washed with milliQ water twice before they were embedded in a liquid OCT, an embedding medium used to aid sectioning of frozen tissue samples in a cryostat (Thermo Fisher Scientific, New Zealand). The liquid OCT blocks were frozen at $-20{ }^{\circ} \mathrm{C}$ for at least $24 \mathrm{~h}$. Sections ( $7 \mu \mathrm{m}$ thick) from the block of frozen OCT were cut using a CM186UV Cryostat (Lieca BIOSYSTEM, 
Deutschland). Immunofluorescent staining was carried out on both cell lines with anti-EGFR (SC120), anti-Her-2 (SC-7301), and anti-c-Met (SC10) primary antibodies (Santa Cruz). Fluorescent images were captured using an epifluorescence microscope with a $40 \times$ / 1.3 N.A. oil/DIC objective lens (AxioVision 4.5. Apotome software, Carl Zeiss, Oberkochen, Germany).

\section{Immunoblotting Analysis}

Cell clusters and aggregates were harvested by centrifugation at $400 \mathrm{~g}$ for $5 \mathrm{~min}$, and the cell pellets were lyzed in cold RIPA buffer $(50 \mathrm{mM}$ Tris- $\mathrm{HCl} \mathrm{pH}$ 7.4, $100 \mathrm{mM} \mathrm{NaCl}, 5 \mathrm{mM}$ EDTA, $1 \%$ NP-40, $0.1 \%$ SDS, $0.5 \% \mathrm{Na}$ deoxycholate, $1 \mathrm{mM} \mathrm{Na} \mathrm{NO}_{3}$ containing protease inhibitor cocktail tablets (Complete Mini, Roche, New Zealand). The cell lysates were left on ice for a further $30 \mathrm{~min}$. Sample buffer $[0.2 \% \quad(\mathrm{v} / \mathrm{v})$ bromophenol blue, 25\% (v/v) glycerol, 10\% SDS in Tris- $\mathrm{HCl}$, and $\mathrm{pH}$ 6.8] was added and protein lysates were boiled for $10 \mathrm{~min}$. Prior to loading, the cell lysates were mixed and centrifuged at $9700 \mathrm{~g}$ for $5 \mathrm{~min}$. A total of $10 \mu \mathrm{g}$ protein lysate was loaded and separated by SDS-PAGE using a 7\% stacking gel and a $10 \%$ separating gel. The SDS-PAGE was run at $120 \mathrm{~V}$ using Tris-glycine running buffer. The SDS-PAGE markers used were MagicMark ${ }^{\mathrm{TM}}$ XP Western Standard (Thermo Fisher Scientific, New Zealand) and Precision Plus Protein standard (Bio-Rad, Hercules, USA). Separated proteins were electro-blotted onto a poly-vinyl membrane (PVDF) (GE Healthcare Life Sciences, New Zealand). The electro blot was run at $100 \mathrm{~V}$ for $60 \mathrm{~min}$ in cold Tris-glycine running buffer containing $10 \% \mathrm{v} / \mathrm{v}$ methanol. The membranes were blocked for 60 min with either 5\% (w/v) non-fat skim milk (Pams brand, New World, New Zealand) or 1\% (w/v) bovine serum albumin (Thermo Fisher Scientific, New Zealand) made up in TBS-T buffer or with Pierce Protein-Free Blocking Buffer (Thermo Scientific, New Zealand). Antibodies (detailed below) were diluted from 1:500 to $1: 1000$ with the appropriate blocking solution. Membranes were incubated with the primary antibodies overnight at $4{ }^{\circ} \mathrm{C}$. The membranes were washed with TBS-T buffer on an orbital shaker for $4 \times 10 \mathrm{~min}$ and then incubated with secondary antibody on an orbital shaker for $90 \mathrm{~min}$ at room temperature. Membranes were further washed four times with TBS-T. Antibody localization was determined using a chemiluminescent detection kit (Amersham ECL Prime Western Blotting Detection Reagent Kit, GE Healthcare). The protein bands were visualized and a densitometry analysis was performed using Alliance 4.7, Unitec (Cambridge, UK). Cell lysates were collected from at least three separated cell culture experiments. The primary antibodies used in this study were anti-PCNA (sc-25280), anti-GAPDH (sc-25778), anti-EGFR (sc-03), anti-p-EGFR (sc-101668), anti-pHER2 (sc-12352-R), anti-ERK (sc-94), anti-pERK1/2 (sc-7383), Anti-c-Met (sc-10), anti-p-Met (sc-101736), anti-Akt (sc-8312), and anti-p-Akt (sc-101629) (all from Santa Cruz Biotechnology Inc., Santa Cruz, CA, USA, apart from the anti-Her2 which was purchased from BD Biosciences (Auckland, New Zealand)). The two secondary antibodies used in this study were bovine anti-rabbit IgG-HRP (sc-2385) and bovine anti-mouse IgG-HRP (sc-2380).

\section{Statistical Analysis}

Statistical analysis of data was carried out using Prism graph pad. One-way ANOVAs were carried out where $p<0.05{ }^{(*)}, p<0.01^{(* *}$, 
$p<0.001^{\left({ }^{* *}\right)}$, and $\left.p<0.0001^{(* * * *}\right)$ were considered to indicate levels of statistical significance. Prior to analysis percentile and ratio-metric values were logarithmically transformed. All data are presented as mean \pm SEM. Each experiment was repeated at least three times.

\section{RESULTS}

\section{Morphology and Expression EGFR, Her-2,} and c-Met

OVCAR-5 cells formed small cell clusters when cultured on a non-adherent surface (Fig. 1a). In contrast, SKOV-3 cells formed large cellular aggregates with dense multicellular structures (Fig. 1b). To determine the presence of cell receptors, we immunofluorescently labeled OVCAR-5 clusters and SKOV-3 cellular aggregates. OVCAR-5 clusters were EGFR (Fig. 1c) and c-Met positive (Fig. 1g), but had low expression of Her-2 (Fig. 1e). SKOV-3 aggregates were EGFR, Her-2 and c-Met positive (Fig. 1d, f, h).

\section{EGF and HGF Increase the Growth of OVCAR-5 Clusters and SKOV-3 Aggregates}

We chose two concentrations of the growth factor EGF and HGF; a physiological concentration $(0.2 \mathrm{ng} / \mathrm{ml})$ that approximates to that present in ovarian cancer patients, and a concentration that is commonly used in in vitro studies $(20 \mathrm{ng} / \mathrm{ml})$. The growth of OVCAR-5 cell clusters was not increased in the presence of the physiological concentration of growth factor $(p=0.4076)$. However, the higher
OVCAR-5
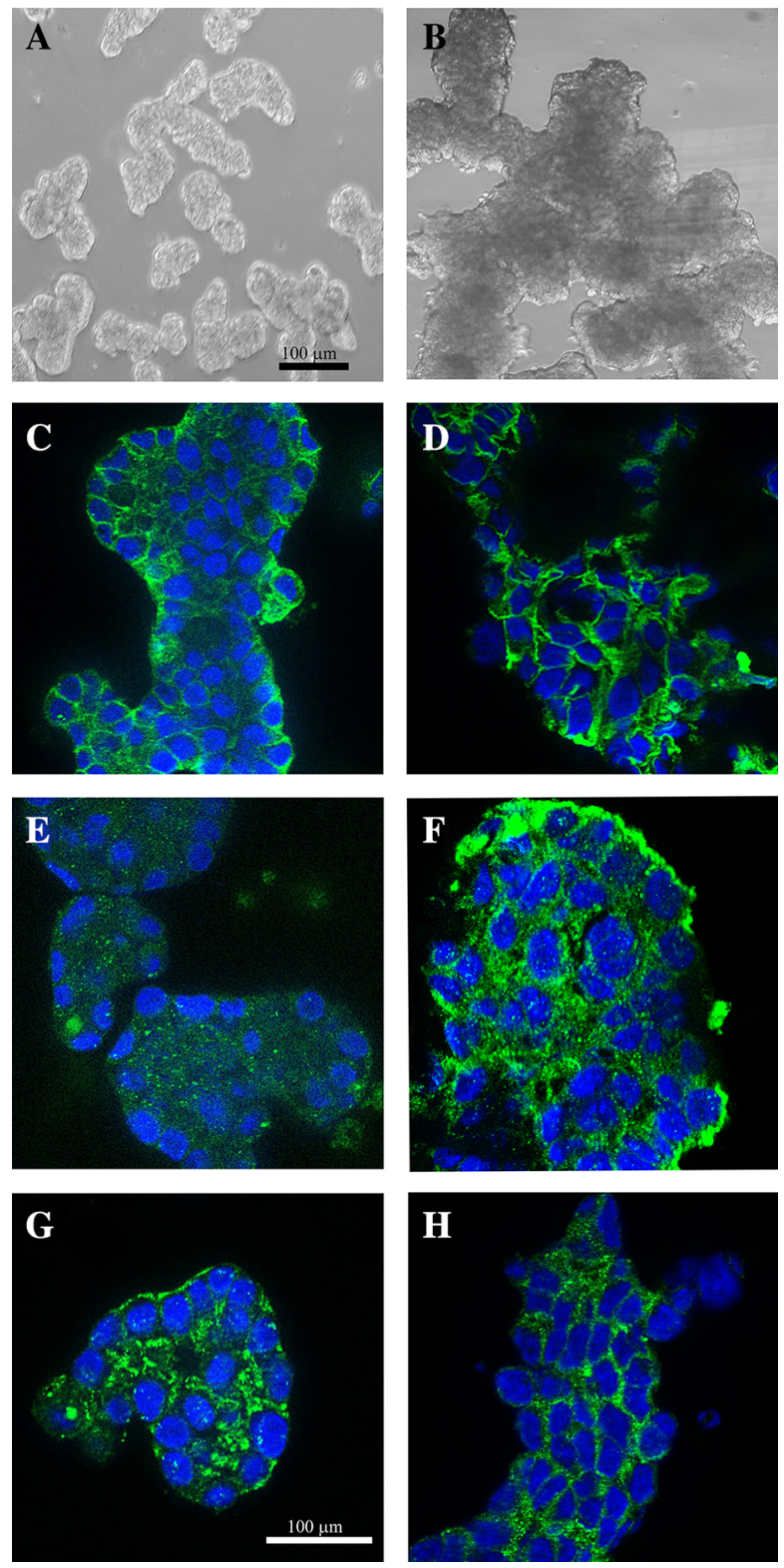

Fig. 1 Morphology of cell clusters and the expression of EGFR, Her-2 and c-Met. Microscopic images of OVCAR-5 ovarian cancer cell clusters (a) and SKOV-3 ovarian cancer cell aggregates (b). The expression of epidermal growth factor receptor (EGFR) in OVCAR-5 (c) and SKOV-3 (d). Total expression of human epidermal growth factor receptor-2 (Her-2) in OVCAR-5 (e) and SKOV-3 (f). Total expression of mesenchymal epithelial transition factor (c-Met) receptors in OVCAR-5 (g) and SKOV-3 (h) 


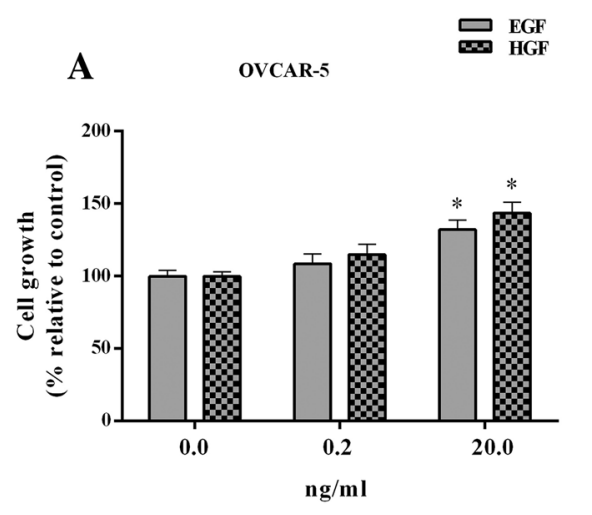

C

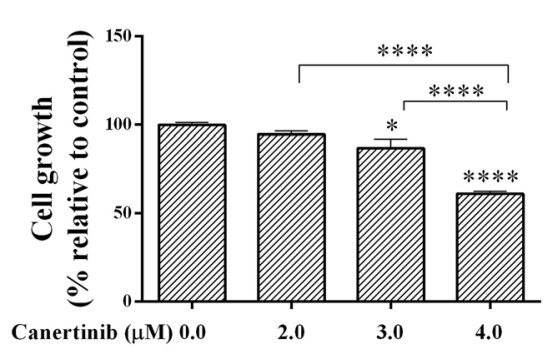

$0.2 \mathrm{ng} / \mathrm{ml} \mathrm{GF}$

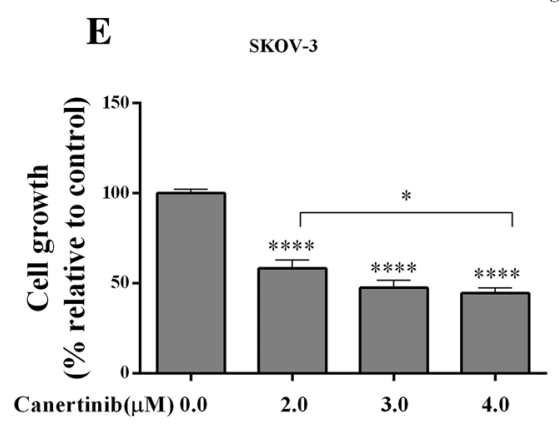

Fig. 2 Combined growth factors induce cell growth and canertinib inhibits cell growth of ovarian cancer cells. Growth stimulation of OVCAR-5 (a), SKOV-3 (b) cells incubated with 0.2 and $20 \mathrm{ng} / \mathrm{ml}$ epidermal growth factor, EGF, or hepatocyte growth factor, HGF. Canertinib inhibited cell growth of OVCAR-5 in a dose-dependent manner in the presence of $0.2 \mathrm{ng} / \mathrm{ml}(\mathbf{c})$ and $20 \mathrm{ng} / \mathrm{ml}$ (d) combined growth factors. Cell growth of SKOV-3

concentration significantly increased growth $(p>0.0001)$ (Fig. 2a). Both concentrations of EGF and HGF significantly increased growth $(p>0.0001)$ in the SKOV-3 cell aggregates (Fig. 2b).
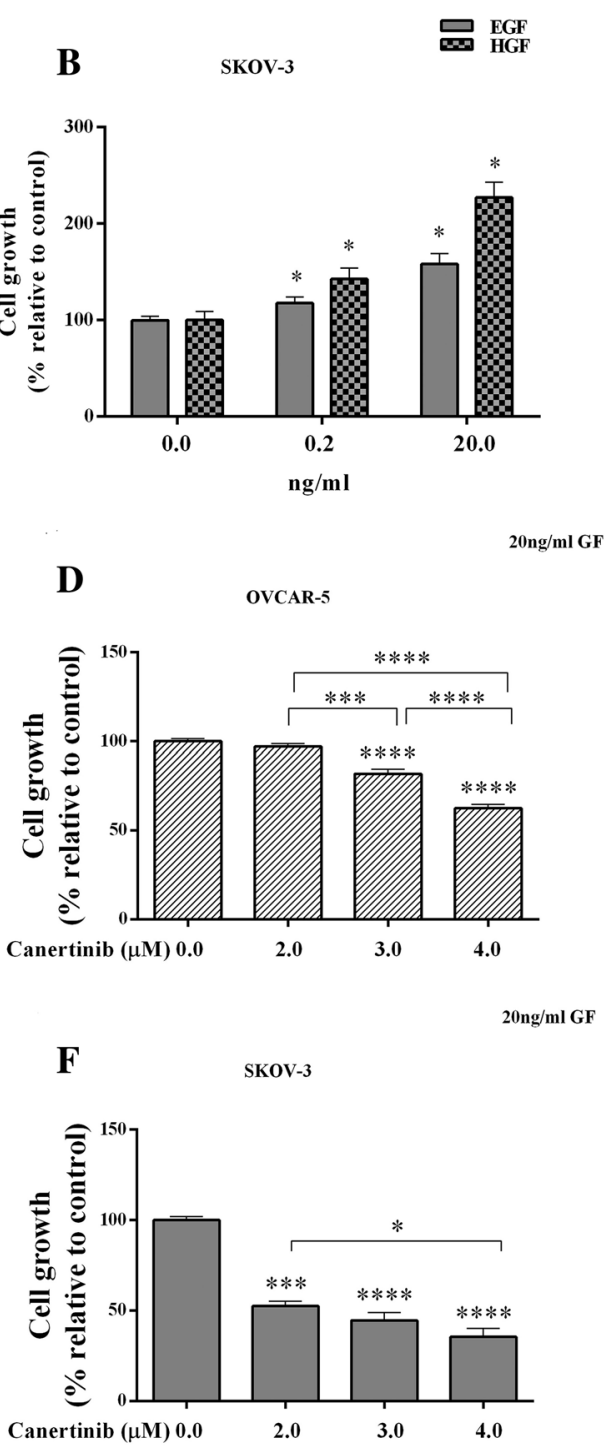

aggregates was markedly reduced by canertinib in the presence of combined growth factors $(\mathbf{e}, \mathbf{f})$. All experiments were independently performed at least three times with triplicates. Data analyzed logarithmically using one-way ANOVA. Data considered statistically significant are indicated as $\left.p<0.05\left({ }^{*}\right), p<0.01\left({ }^{* *}\right), p<0.001{ }^{(* *}\right)$, and $p<0.0001\left({ }^{* * *}\right)$ when compared to the control or the other doses

\section{Canertinib and PHA665752 Alone Inhibit the Growth of Clusters and Aggregates}

We next investigated whether growth of cell clusters and aggregates could be inhibited by the 


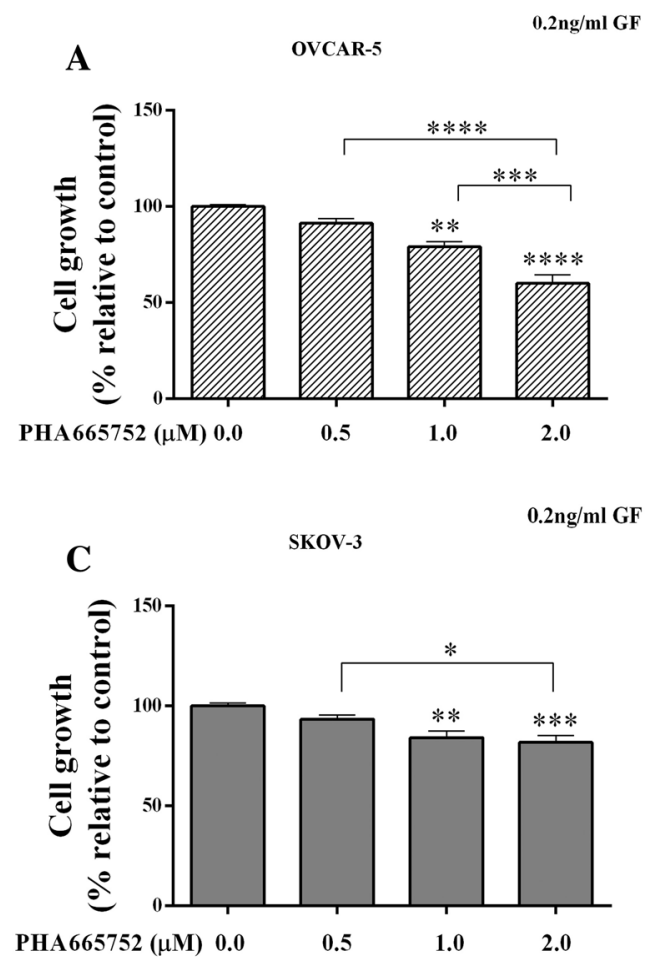

Fig. 3 Inhibition of c-Met inhibitor, PHA665752 on cell growth of ovarian cancer cells. PHA665752 inhibited cell growth of OVCAR- 5 clusters in a dose-dependent manner in the presence of $0.2 \mathrm{ng} / \mathrm{ml} \mathrm{(a)} \mathrm{and} 20 \mathrm{ng} / \mathrm{ml}$ (b) combined growth factors. Cell growth of SKOV-3 aggregates was marginally reduced by PHA665752 in the presence of combined growth factors (c, d). All

EGFR/Her-2 inhibitor, canertinib. In their in vivo microenvironment, floating ovarian cancer cells are exposed to a mixture of growth factors (GF). Therefore, we stimulated the cells with the mixture of EGF and HGF. Canertinib inhibited the growth activity in OVCAR-5 cell clusters, in a concentration-dependent manner, in the presence of low and high concentrations of combined growth factors $(p>0.0001)$ (Fig. 2c, d). The inhibitor was very potent against SKOV-3 cell aggregates $(p>0.0001) \quad$ (Fig. $2 \mathrm{e}, \quad \mathrm{f})$. Interestingly, the inhibition of canertinib was growth factor independent.

We then examined the effect of PHA665752 on growth. PHA665752 inhibited growth of OVCAR-5 clusters in a concentration-dependent
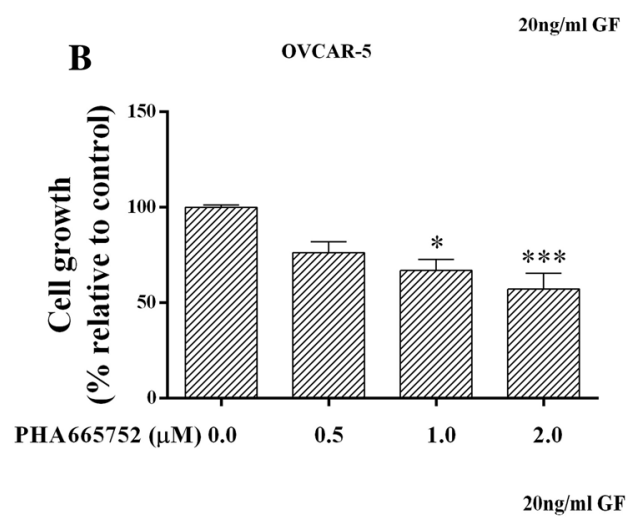

D

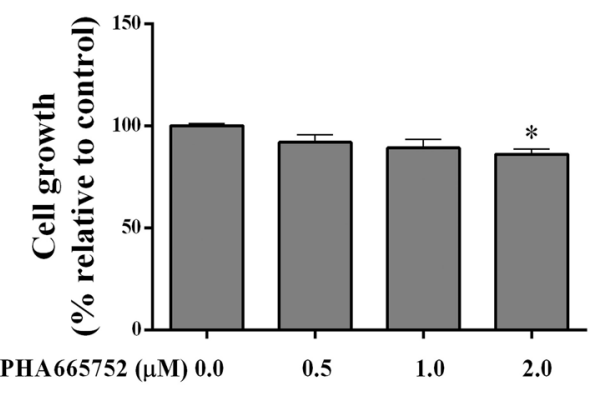

experiments were independently performed at least three times with triplicates. Data analyzed logarithmically using one-way ANOVA. Data considered statistically significant are indicated as $p<0.05\left(^{*}\right), p<0.01\left(^{* *}\right), p<0.001\left(^{* * *}\right)$, and $\left.p<0.0001{ }^{* * * *}\right)$ when compared to the control or the other doses

manner $(p>0.0001)$ (Fig. 3a, b). Its effect on SKOV-3 aggregates was less pronounced, but there still was a decrease in growth $(p>0.05)$ (Fig. 3c, d). Interestingly, growth inhibition by PHA665752 in the presence of low and high concentration mixtures of growth factors was not statistically different (data not shown).

\section{Effect of a Combination of Both Canertinib and PHA665752}

We investigated the effects of a combination of canertinib and PHA665752 at respective concentrations of $3 \mu \mathrm{M}$ and $1 \mu \mathrm{M}$, which were the lowest effective doses from the single drug treatment experiments. The combination of 


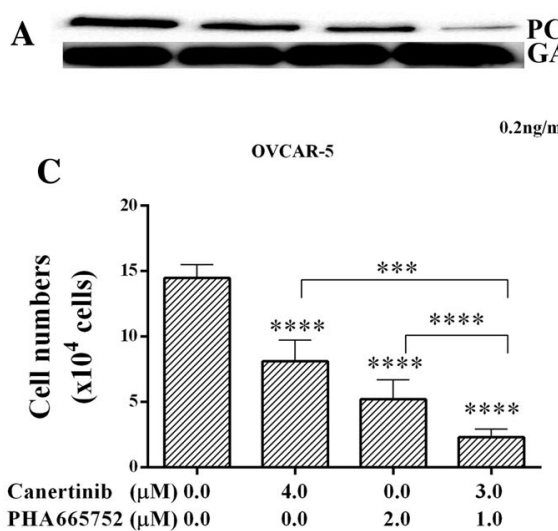

Fig. 4 The effect of the combination of canertinib and PHA665752 on the growth of ovarian cancer cells. The expression of proliferative cell nuclear antigen (PCNA) and a reference protein (GAPDH) in ovarian cancer cells treated with single inhibitors and combination in OVCAR-5 (a) and SKOV-3 (b). Cell numbers of OVCAR-5 cells (c) and SKOV-3 (d) were reduced with single and combination of both inhibitors compared to

these concentrations reduced total expression of the cell proliferative protein marker, PCNA in OVCAR-5 (Fig. 4a) and SKOV-3 (Fig. 4b) cells. Growth was more reduced with the inhibitor combination, than with the respective single inhibitor alone, in both OVCAR-5 clusters (Fig. 4c) and SKOV-3 aggregates (Fig. 4d) $(p>0.0001)$ in the presence of $0.2 \mathrm{ng} / \mathrm{ml} \mathrm{GF}$. Similar patterns of inhibition were obtained with $20 \mathrm{ng} / \mathrm{ml}$ GF for OVCAR-5 and SKOV-3 (Fig. 5).

\section{Canertinib and PHA665752 Reduce \\ Expression of EGFR, Her-2 c-Met, and Their Downstream Signaling Molecules in OVCAR-5 Cell Clusters}

Both single and combined applications of the inhibitors significantly reduced p-EGFR (Fig. 6a, b) in OVCAR-5 cell clusters in the presence of $0.2 \mathrm{ng} / \mathrm{ml}$ GF. However, the total expression of EGFR was only reduced in canertinib-treated cells (Fig. 6c). Both c-Met and phosphorylated-c-Met proteins were significantly reduced with a single treatment of PHA665752, and this was further

\section{B}
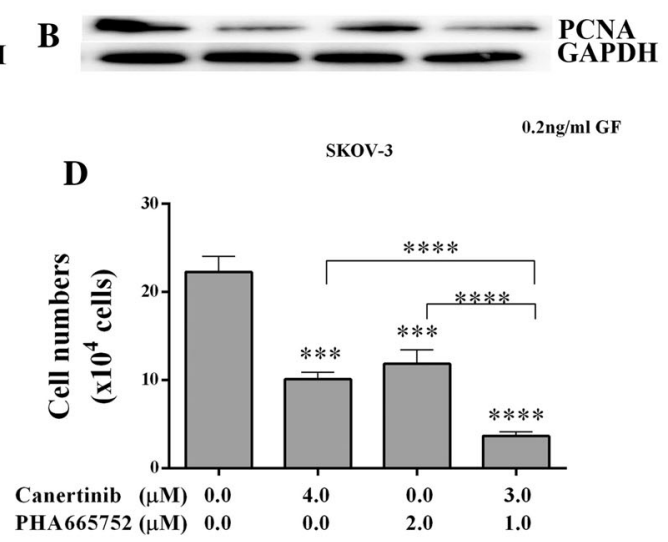

untreated cells in presence of $0.2 \mathrm{ng} / \mathrm{ml}$ combined growth factors. All experiments were independently performed at least three times with triplicates. Data analyzed using one-way ANOVA. Data considered statistically significant are indicated as $p<0.05\left(^{*}\right), p<0.01\left(^{* *}\right), p<0.001\left(^{(* *)}\right.$, and $p<0.0001\left(^{* * * *}\right)$ when compared to the control or the other doses

decreased with the combination (Fig. 6a, d, e). The combination of inhibitors reduced the total expression of Akt (Fig. 6g) and there was a tendency for reduction of Akt phosphorylation (Fig. 6f). The phosphorylation of Erk was reduced in a single treatment alone, but there was greater reduction of $\mathrm{p}$-Erk in the combined inhibitors (Fig. 6h). The total expression of Erk (Fig. 6i) was unchanged. Expression of Her-2 was undetectable in OVCAR-5 cell clusters. With $20 \mathrm{ng} / \mathrm{ml}$ combined growth factors, an overall reduction of total expression and phosphorylation of EGFR, and c-Met was observed with the inhibitor combination (Fig. 7). Reductions in p-EGFR, EGFR, p-Met, Met, p-Akt, Akt and p-Erk were observed.

\section{Canertinib and PHA665752 Reduce}

the Expression of EGFR, Her-2 c-MET, and Their Downstream Signaling Molecules in SKOV-3 Cellular Aggregates

Single treatment of SKOV-3 cell aggregates with canertinib reduced the amount of p-EGFR 


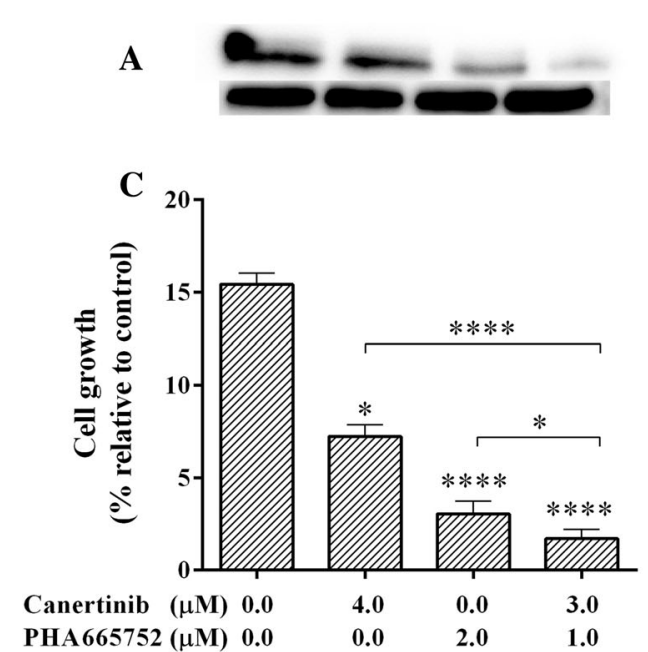

Fig. 5 The effect of the combination of canertinib and PHA665752 on the growth of ovarian cancer cell in the presence of $20 \mathrm{ng} / \mathrm{ml}$ combined growth factors. Expression of proliferative cell nuclear antigen (PCNA) and a reference protein $(\mathrm{GAPDH})$ in ovarian cancer cell clusters treated with single inhibitors and combination in OVCAR-5 (a) and SKOV-3 (b). Cell numbers of OVCAR-5 cells (c) and SKOV-3 (d) were reduced with

(Fig. 8a), while the application of PHA665752 alone did not reduce p-EGFR. The combination treatment gave a similar result to canertinib alone (Fig. 8b). The total expression of EGFR itself was also reduced with canertinib, and with the combination treatment (Fig. 8c). Phosphorylation and total expression of Her-2 was significantly reduced in both the canertinib and the combination treatment (Fig. 8d, e). Canertinib alone and the combination significantly reduced the phosphorylation of c-Met (Fig. 8f). The single inhibitor treatment reduced the total expression of c-Met, but a greater reduction was observed in the combination (Fig. 8g). The reduction of p-Akt, and p-Erk were also notable in the combination treatment. The total expression of Erk was slightly reduced in the canertinib and combination treatment. Similar results were obtained when cells were activated with $20 \mathrm{ng}$ / ml combined GF (Fig. 9).
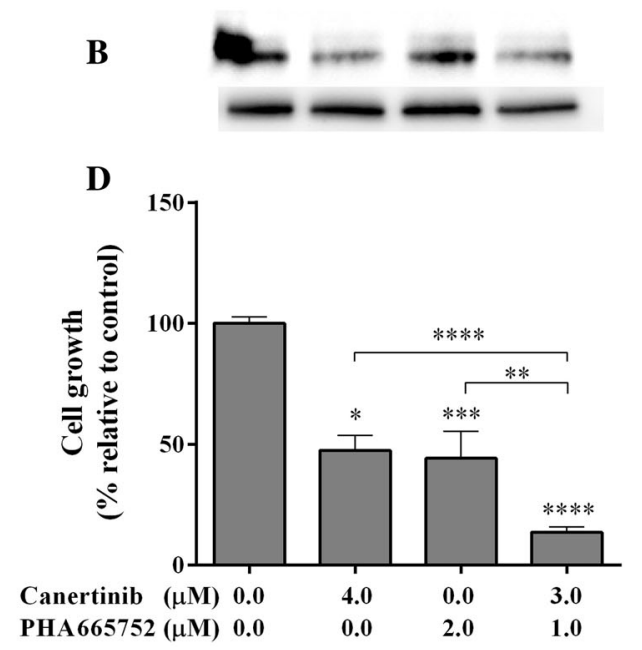

single and combination of both inhibitors compared to untreated cells in presence of $20 \mathrm{ng} / \mathrm{ml}$ combined growth factors. All experiments were independently performed at least three times with triplicates. Data analyzed using one-way ANOVA. Data considered statistically significant are indicated as $p<0.05\left(^{*}\right), p<0.01\left(^{* *}\right), p<0.001\left(^{* * *}\right)$, and $p<0.0001\left({ }^{* * *}\right)$ when compared to the control or the other doses

\section{DISCUSSION}

A subset of advanced ovarian cancer cells have previously been shown to express high levels of receptor tyrosine kinases that are associated with rapid growth and proliferation. EGFR and Her-2 were upregulated in 53\% and 25\% of patients with advanced ovarian cancers, respectively, and these were thought to be associated with resistance to chemotherapy and a poor prognosis [8]. Likewise, Swada et al. have shown that c-Met expression increased in $11 \%$ of ovarian cancer patients [17], and Davies et al. report that $96 \%$ of ovarian cancer patients have positive expression of c-Met in their cancerous tissue [10]. Thus, it is very plausible that cells may have an ability to activate multiple receptors, and this rationale has been described by other studies [2, 17, 18]. Co-activation of multiple receptor tyrosine kinases may reduce the 
A control canertinib PHA combination

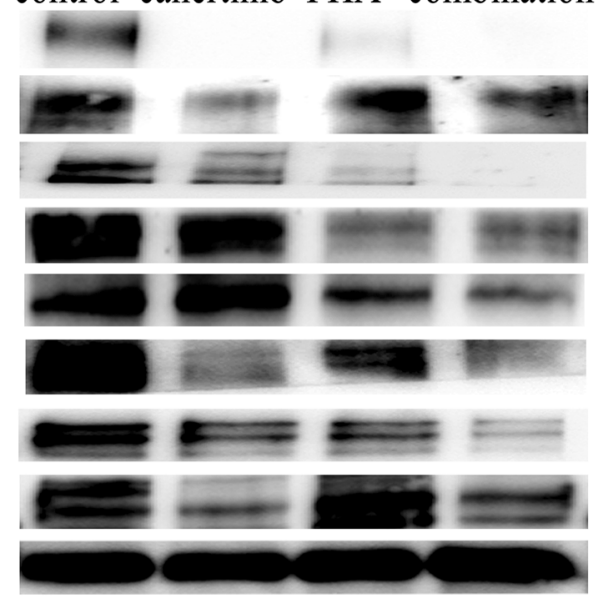

F

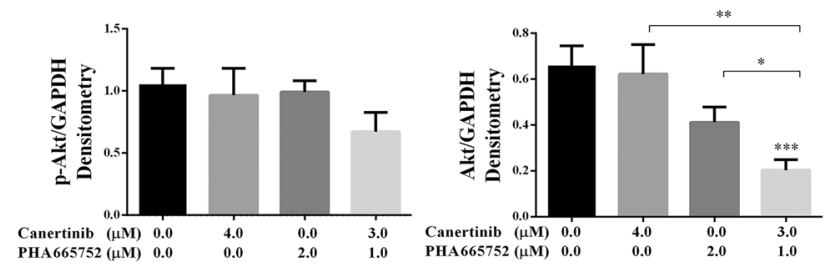

Fig. 6 Inhibition of selective protein molecules in the presence of canertinib and PHA665752 in OVCAR-5 cell clusters with $0.2 \mathrm{ng} / \mathrm{ml}$ combined growth factors. Total protein expression and phosphorylation of EGFR, Her-2, c-Met, Akt and Erk in single and combination of inhibitors. All experiments were independently performed

clinical efficacy of any single drug that targets one of the receptors [19, 20]. Therefore, targeting multiple receptor tyrosine kinases may improve clinical efficacy. Our study attempts to employ such a combined approach by targeting the concurrent activation of EGFR, Her-2 and c-Met. Our study has used a 3D cell culture, in which the generation of cell clusters and aggregates replicates the phenotypic and cellular heterogeneity of floating ovarian malignant cells that are present in ascitic fluid. As such these experiments may be a better representation of the possible response to the combination of drugs in vivo [21, 22].

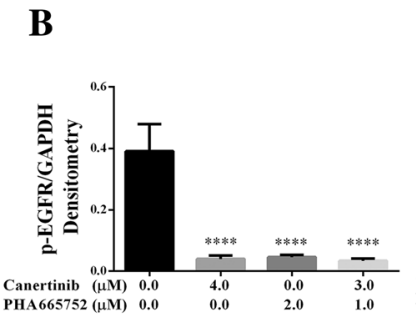

C
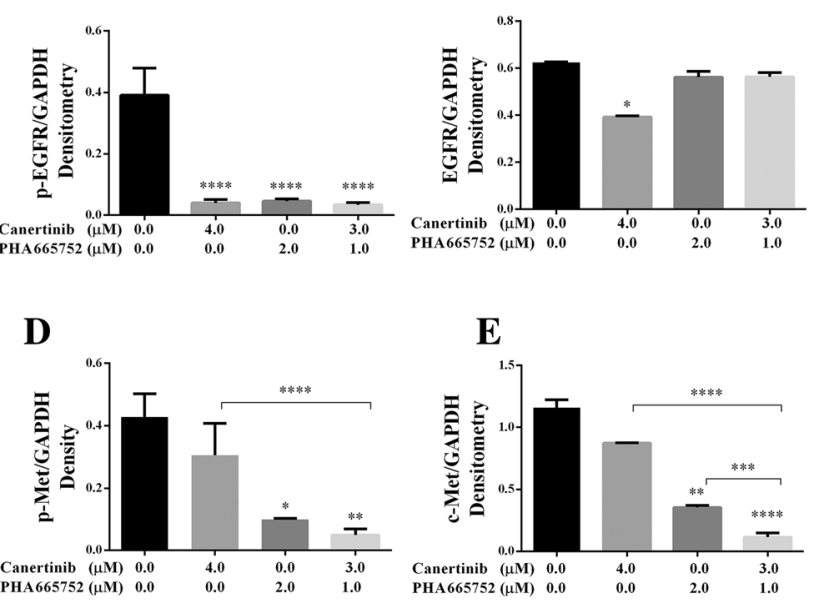

H

I
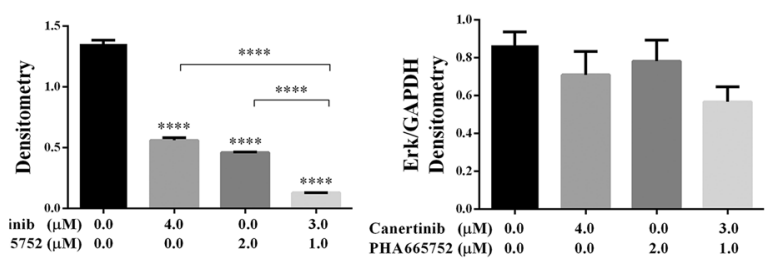

at least three times with triplicates. Data analyzed logarithmically using one-way ANOVA. Data considered statistically significant are indicated as $p<0.05\left({ }^{*}\right)$, $\left.p<0.01{ }^{(* *)}, p<0.001{ }^{(* * *}\right)$, and $p<0.0001^{\left({ }^{* * *}\right)}$ when compared to the control or other doses

Consistent with previous reports, we found that the OVCAR-5 cells formed small clusters while the SKOV-3 cells formed aggregates $[23,24]$. We also show that OVCAR-5 cell clusters express high levels of EGFR and c-Met, but low levels of Her-2 and that the SKOV-3 aggregates express high levels of all three receptors. These observations are consistent with a previous study [25]. In previous studies, a variety of EGF and HGF concentrations have been used ranging from 10 to $200 \mathrm{ng} / \mathrm{ml}$ $[26,27]$. However, these concentrations are not physiologically relevant in women with advanced ovarian cancer [28]. We show that a concentration of $0.2 \mathrm{ng} / \mathrm{ml}$, which is a more 
A

\section{GF OVCAR-5}

control canertinib PHA combination

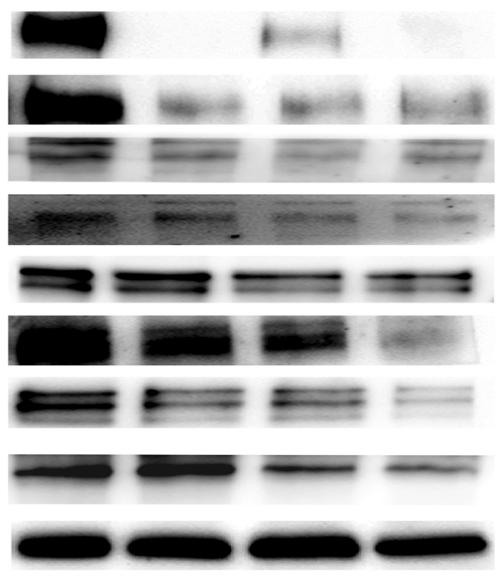

p-EGFR

EGFR

p-Met

c-MET

p-Akt

Akt

p-Erk

Erk

GAPDH
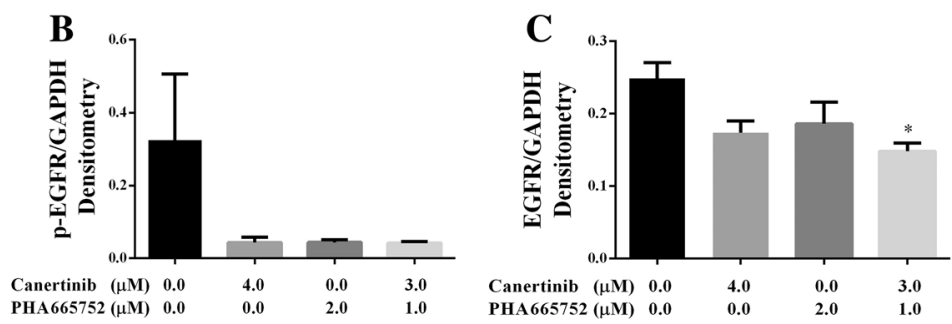

D

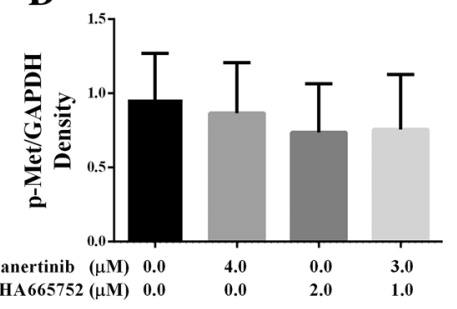

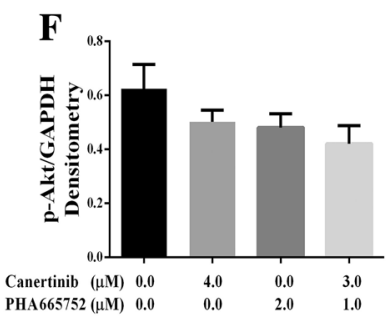

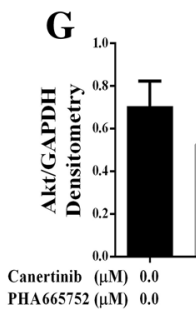

Fig. 7 Inhibition of selective protein molecules in the presence of canertinib and PHA665752 in OVCAR-5 cell clusters with $20 \mathrm{ng} / \mathrm{ml}$ combined growth factors. Total protein expression and phosphorylation of EGFR, Her-2, c-Met, Akt and Erk in single and combination of inhibitors. All experiments were independently performed

physiologically relevant level, elicits no significant change in the growth of OVCAR-5 line, compared to a concentration of $20 \mathrm{ng} / \mathrm{ml}$. However, the growth of SKOV-3 cell line was growth factor dependent. It is unclear therefore to what extent EGF and HGF determine ovarian cell growth in physiological conditions.

We have assessed the effect of canertinib, an irreversible dual inhibitor for EGFR family of receptor tyrosine kinases, and PHA665752, a reversible, specific inhibitor for c-MET protein, on both cell lines in the presence of EGF and HGF which are the respective ligands for the
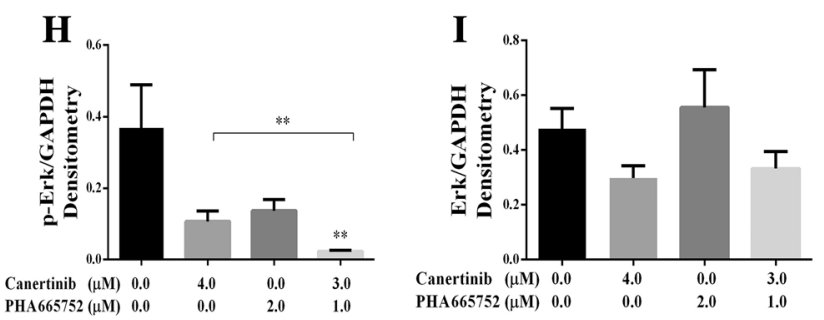

at least three times with triplicates. Data analyzed logarithmically using one-way ANOVA. Data considered statistically significant are indicated as $p<0.05\left({ }^{*}\right)$, $\left.\left.p<0.01{ }^{(* *}\right), p<0.001{ }^{(* * *}\right)$, and $p<0.0001{ }^{(* * *)}$ when compared to the control or the other doses

receptors [29]. In our study, the selective concentrations of single drug treatments were chosen on the basis of concentrations in a mouse model previously described [30]. Canertinib binds irreversibly to the ATP pocket of the intracellular domain of ErbB family receptor tyrosine kinases, forming a covalent bond that irreversibly blocks EGFR, Her-2 and Her-3 signal transduction. Reversible small molecule inhibitors of EGFR such as Gefitinib (ZD1839, Iressa) and Erlotinib (OSI-774, Tarceva) have been approved by the FDA for treatment of NSCLC [31]. The anti-growth 
A

\subsection{GF SKOV-3}

control canertinib PHA combination
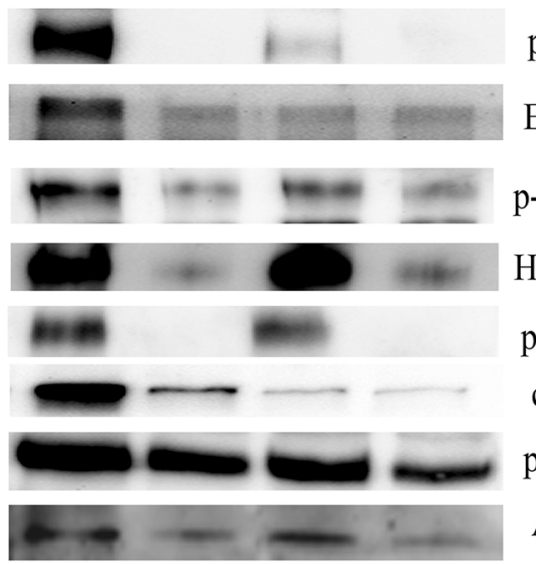

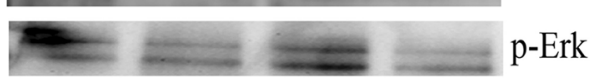

$= \pm$ Erk

$\longrightarrow$ GAPDH

Akt
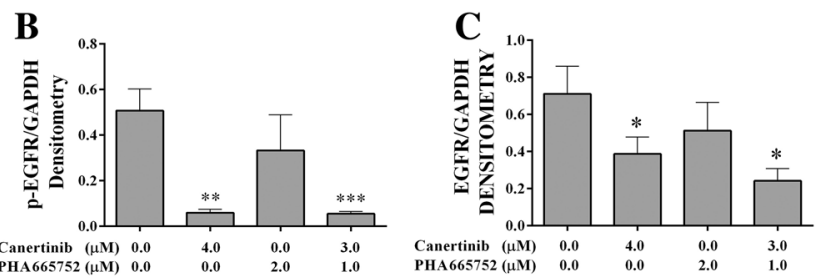

p-HER-2
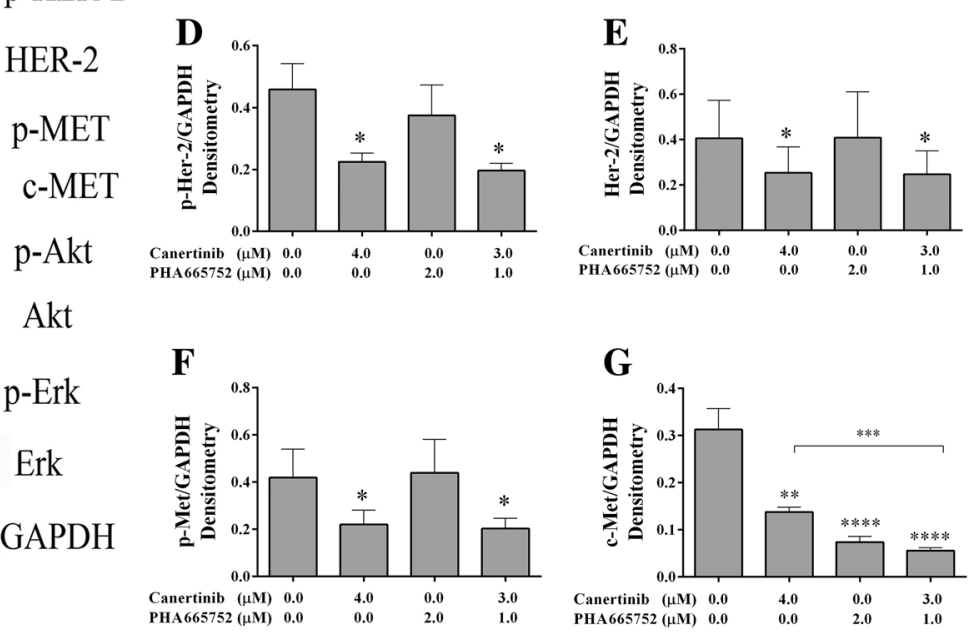

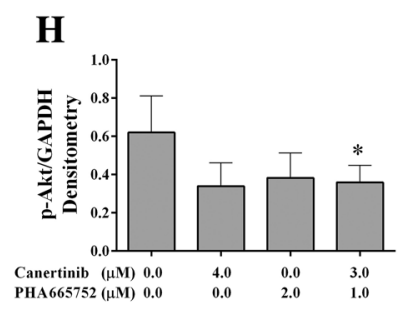

I

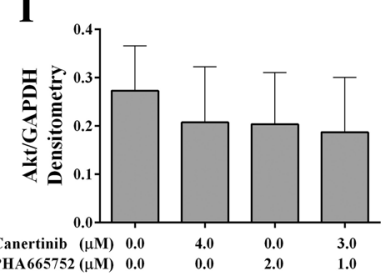

Fig. 8 Inhibition of selective protein molecules in the presence of canertinib and PHA665752 in SKOV-3 cell clusters with $0.2 \mathrm{ng} / \mathrm{ml}$ combined growth factors. Total protein expression and phosphorylation of EGFR, Her-2, c-Met, Akt and Erk in single and combination of inhibitors (a). All experiments were independently

properties of these drugs have been explored in other EGFR-positive malignancies, and unfortunately the majority of these trials have failed to exhibit prolonged clinical effects $[32,33]$. The difference between canertinib, and gefitinib and erlotinib [33], is that canertinib irreversibly binds to the active site of ATP, completely blocking the ATP-binding process and thereby decreasing the activity of EGFR and Her-2 permanently. Therefore, there
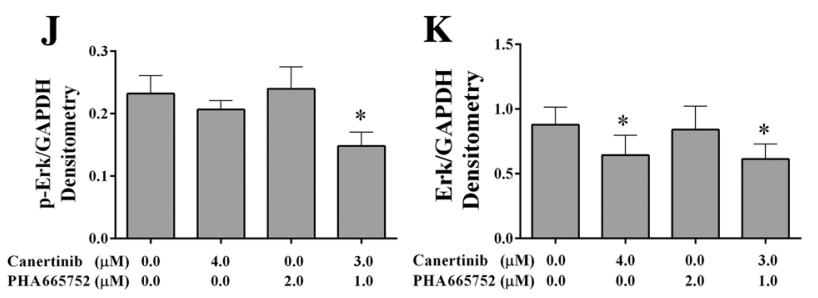

performed at least three times with triplicates. Data analyzed logarithmically using one-way ANOVA. Data considered statistically significant are indicated as $p<0.05$ $\left({ }^{*}\right), p<0.01\left(^{(* *}\right), p<0.001\left(^{(* *}\right)$, and $\left.p<0.0001{ }^{* * * *}\right)$ when compared to the control or the other doses

is a good rationale for utilizing an irreversible inhibitor, in order to prolong the suppression of EGFR family activity and their downstream molecules [34].

We show that canertinib inhibits growth of SKOV-3 cell aggregates in a dose-dependent fashion. This effect may be due to the abundant expression of EGFR and Her-2. In contrast, OVCAR-5 cell clusters exhibited less sensitivity to canertinib, possibly because they 
A

\section{GF SKOV-3}

control canertinib PHA combination

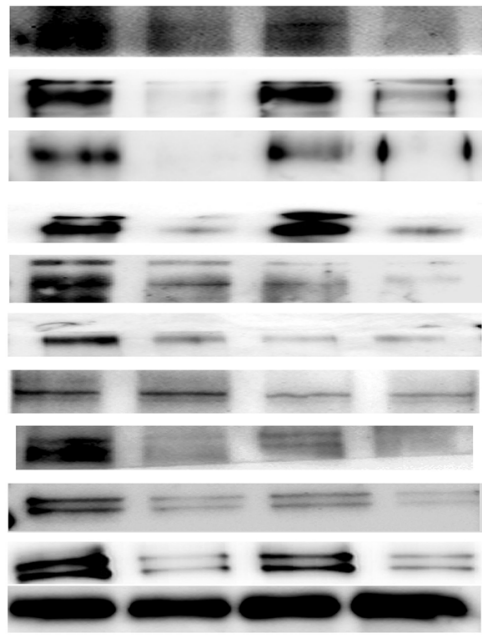

p-EGFR EGFR

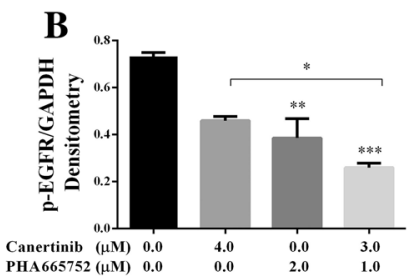
$\mathrm{p}-\mathrm{HER}-2$ HER-2 p-Met c-Met p-Akt

Akt

p-Erk
Erk
GAPDH

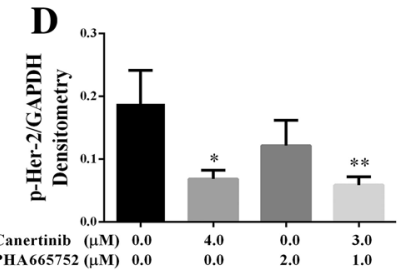

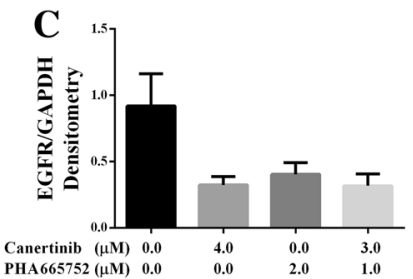
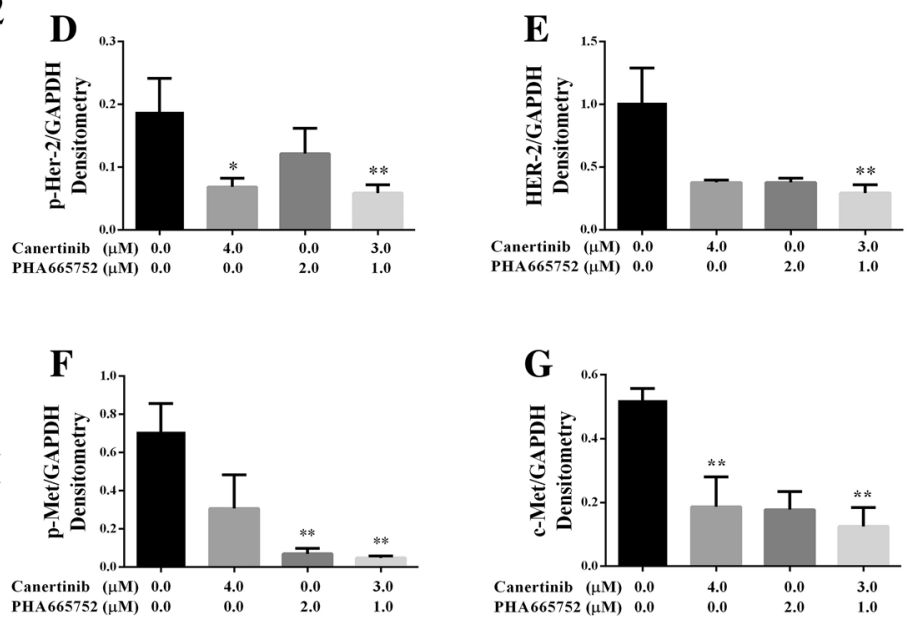

I
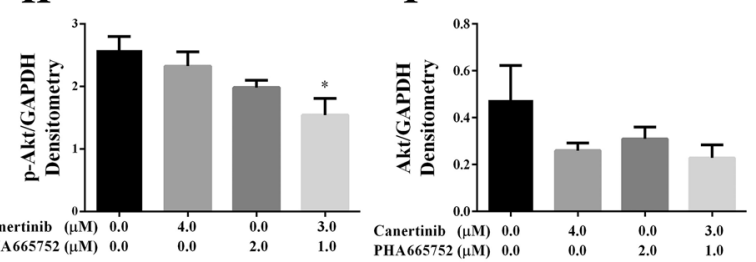
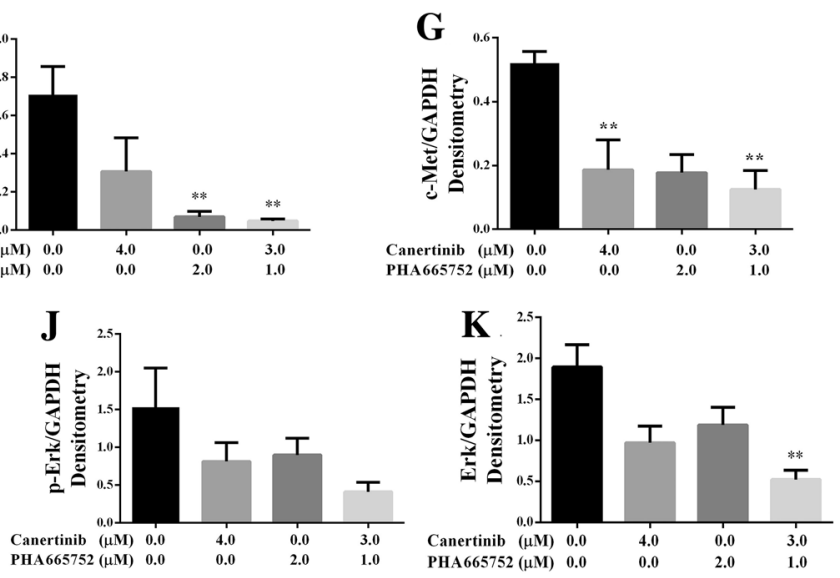

Fig. 9 Inhibition of selective protein molecules in the presence of canertinib and PHA665752 in SKOV-3 cell aggregates with $20 \mathrm{ng} / \mathrm{ml}$ combined growth factors. Total protein expression and phosphorylation of EGFR, Her-2, c-Met, Akt and Erk in single and combination of inhibitors. All experiments were independently performed

might have other downstream mutations that facilitate cell survival [35]. Irwin, et al. showed that canertinib at 0.1 and $5 \mu \mathrm{M}$ inhibit the proliferative capacity of acute lymphoblastic leukemia cells [36]. Canertinib used as a single agent showed clinical responsiveness in Her-2 positive tumors of breast cancer patients [37].

In our study, we also demonstrate that c-Met inhibitor PHA665752, when used as a single agent, inhibits SKOV-3 and OVCAR-5 growth in a dose-dependent manner. However, SKOV-3

at least three times with triplicates. Data analyzed logarithmically using one-way ANOVA. Data considered statistically significant are indicated as $p<0.05\left(^{*}\right)$, $\left.p<0.01{ }^{* *}\right), p<0.001\left(^{* * *}\right)$, and $p<0.0001\left(^{(* * *}\right)$ when compared to the control or the other doses

cell aggregates seem to be less responsive to the c-Met inhibitor, compared to OVCAR-5 clusters. One possible explanation is that SKOV-3 cells have a high level of Her-2 and that the SKOV-3 cells may be able to resist the inhibitory action of the c-Met inhibitor. As a single agent, PHA665752 has been shown to induce apoptosis, cease cell proliferation and spread in lung adenocarcinoma cells with $k$-Ras gene mutations [38]. Ma et al. demonstrated that PHA665752 inhibited the growth of 
BaF3.TPR-Met cells in a dose-dependent manner [39] and Christensen et al. showed that PHA665752 at a concentration range of $0.1-5.0 \mu \mathrm{M}$ inhibited growth of gastric, pancreatic, and lung carcinoma cell lines $[14,40]$. Other studies have shown NSCLC and gastric cancer cells are sensitive to concentrations of PHA665752 between 0.01 and $10 \mu \mathrm{M}$ [9].

In our study, we demonstrate that the combined inhibitors (using the lowest effective single treatment concentration of each inhibitor) elicit a greater reduction of cell growth than a single agent alone. This finding may suggest that the combination of EGFR/ Her-2 and c-Met inhibitors is sufficient to block multiple cellular pathways and that can compromise the growth and survival of cancer cells. The rationale of combined targeting with multiple drugs has been highlighted in recent years. Engelman et al. demonstrated that a combination of gefitinib and PHA665752 reduced cell proliferation more than a single treatment alone, in NSCLC and gastric cancer cell lines [9], while Crosswell et al. indicated that combining PHA665752 with rosiglitazone strongly inhibited cell growth of a neuroblastoma cell line [41]. In addition, Tang et al. demonstrated that the inhibition of both EGFR and c-Met receptors strongly compromised the growth activity of EGFR-mutation mediated erlotinib-resistant lung cancer cells [42].

In clinical trials, the combination of cytotoxic agents with small molecule receptor tyrosine kinase inhibitors or monoclonal antibodies has been also investigated in ovarian and other cancers. The combination of cetuximab, a monoclonal antibody to EGFR, and paclitaxel and carboplatin is adequately tolerated as a primary therapy for ovarian cancer but does not demonstrate the increase of progression-free survival [43]. The combination of lapatinib plus topotecan for the treatment of platinum-resistant ovarian cancer showed limited clinical benefit [44]. Chun et al. showed that a combination of gemcitabine and gefitinib synergistically reduced cell growth of head and neck cancer cells in an in vitro and an in vivo animal model, and the phosphorylation of EGFR and the downstream molecule Erk was also down regulated [45]. Furthermore, breast cancer patients treated with the combination of capecitabine with the Her-2 antibody, trastuzumab, or with lapatinib showed clinical activity, but increased side effects were noticed $[46,47]$. Certainly, the present study is limited given the lack of any preclinical animal model study. This would be essential to confirm the efficacy of our combination inhibitors and to identify potential adverse side effects.

\section{CONCLUSION}

Studying the SKOV-3 and OVCAR-5 ovarian cancer cell lines in vitro, we demonstrate a significant effect on growth of a combination of two tyrosine kinase inhibitors that block three receptor tyrosine kinases. Further work is required to elaborate these effects in animal and human studies. SKOV-3 and OVCAR-5 cell lines do not entirely represent in vivo ovarian cancer cells. Therefore, we need to know if these effects are seen in other cell lines, including primary ovarian cancer cells from patients, and how the effects correlate with the receptor status. The combination of receptor tyrosine kinase inhibitors at effective concentrations may, however, have the effect of increasing toxicity. Animal studies are essential to assess any adverse side effects prior to any clinical trials. 


\section{ACKNOWLEDGMENTS}

The work was supported by a Grant from the Ovarian Cancer Research Foundation (OCRF) Melbourne, Australia and School of Biological Sciences, University of Canterbury, Christchurch, New Zealand. No funding or sponsorship was recived publication of this article. All named authors meet the International Committee of Medical Journal Editors (ICMJE) criteria for authorship for this manuscript, take responsibility for the integrity of the work as a whole, and have given final approval for the version to be published. The Ministry of Education, Iraqi Government, supports the scholarship for WH. WH performed most experiments. KC, PS and AG designed the study and prepared a manuscript. All authors read and approved the final manuscript.

$\begin{array}{lll}\text { Disclosures. Wafaa } & \text { Hassan, } & \text { Kenny } \\ \text { Chitcholtan, Peter Sykes and Ashley } & \text { Garrill } \\ \text { have nothing to disclose. }\end{array}$

Compliance with Ethics Guidelines. This article does not contain any studies with human or animal subjects performed by any of the authors.

Open Access. This article is distributed under the terms of the Creative Commons Attribution-NonCommercial 4.0 International License (http://creativecommons.org/licenses/ by-nc/4.0/), which permits any noncommercial use, distribution, and reproduction in any medium, provided you give appropriate credit to the original author(s) and the source, provide a link to the Creative Commons license, and indicate if changes were made.

\section{REFERENCES}

1. Jemal A, Siegel R, Ward E, Murray T, Xu J, Thun MJ. Cancer statistics, 2007. CA Cancer J Clin. 2007;57(1):43-66.

2. Dienstmann R, De Dosso S, Felip E, Tabernero J. Drug development to overcome resistance to EGFR inhibitors in lung and colorectal cancer. Mol Oncol. 2012;6(1):15-26.

3. Jänne PA, von Pawel J, Cohen RB, Crino L, Butts CA, Olson SS, et al. Multicenter, randomized, phase II trial of CI-1033, an irreversible pan-ERBB inhibitor, for previously treated advanced non-small-cell lung cancer. J Clin Oncol. 2007;25(25):3936-44.

4. Vergote IB, Jimeno A, Joly F, Katsaros D, Coens C, Despierre E, et al. Randomized phase III study of erlotinib versus observation in patients with no evidence of disease progression after first-line platin-based chemotherapy for ovarian carcinoma: a European Organisation for Research and Treatment of Cancer-Gynaecological Cancer Group, and Gynecologic Cancer Intergroup Study. J Clin Oncol. 2013;32:320-6.

5. Campos S, Hamid O, Seiden MV, Oza A, Plante M, Potkul RK, et al. Multicenter, randomized phase II trial of oral CI-1033 for previously treated advanced ovarian cancer. J Clin Oncol. 2005;23(24): 5597-604.

6. Steffensen KD, Waldstrom M, Andersen RF, Olsen DA, Jeppesen U, Knudsen HJ, et al. Protein levels and gene expressions of the epidermal growth factor receptors, HER1, HER2, HER3 and HER4 in benign and malignant ovarian tumors. Int J Oncol. 2008;33(1):195-204.

7. Alper O, Bergmann-Leitner ES, Bennett TA, Hacker NF, Stromberg K, Stetler-Stevenson WG. Epidermal growth factor receptor signaling and the invasive phenotype of ovarian carcinoma cells. J Natl Cancer Inst. 2001;93(18):1375-84.

8. Berchuck A, Kamel A, Whitaker R, Kerns B, Olt G, Kinney R, et al. Overexpression of HER-2/neu is associated with poor survival in advanced epithelial ovarian cancer. Cancer Res. 1990;50(13):4087-91.

9. Engelman JA, Zejnullahu K, Mitsudomi T, Song Y, Hyland C, Park JO, et al. MET amplification leads to gefitinib resistance in lung cancer by activating ERBB3 signaling. Science. 2007;316(5827): 1039-43. 
10. Davies S, Holmes A, Lomo L, Steinkamp MP, Kang $\mathrm{H}$, Muller CY, et al. High incidence of ErbB3, ErbB4, and MET expression in ovarian cancer. Int J Gynecol Pathol. 2014;33(4):402-10.

11. Matte I, Lane D, Laplante C, Garde Granger P, Rancourt C, Piché A. Ovarian cancer ascites enhance the migration of patient-derived peritoneal mesothelial cells via cMet pathway through HGF- dependent and- independent mechanisms. Int J Cancer. 2015;137(2):289-98.

12. Krumbach R, Schüler J, Hofmann M, Giesemann T, Fiebig $\mathrm{H}-\mathrm{H}$, Beckers T. Primary resistance to cetuximab in a panel of patient-derived tumour xenograft models: activation of MET as one mechanism for drug resistance. Eur J Cancer. 2011;47(8):1231-43.

13. Rixe O, Franco SX, Yardley DA, Johnston SR, Martin M, Arun BK, et al. A randomized, phase II, dose-finding study of the pan-ErbB receptor tyrosine-kinase inhibitor CI-1033 in patients with pretreated metastatic breast cancer. Cancer Chemother Pharmacol. 2009;64(6):1139-48.

14. Christensen JG, Schreck R, Burrows J, Kuruganti P, Chan E, Le P, et al. A selective small molecule inhibitor of c-Met kinase inhibits c-Met-dependent phenotypes in vitro and exhibits cytoreductive antitumor activity in vivo. Cancer Res. 2003;63(21):7345-55.

15. Smolle E, Taucher V, Haybaeck J. Malignant ascites in ovarian cancer and the role of targeted therapeutics. Anticancer Res. 2014;34:1553-62.

16. Sheid B. Angiogenic effects of macrophages isolated from ascitic fluid aspirated from women with advanced ovarian cancer. Cancer Lett. 1992;62:153-8.

17. Sawada K, Radjabi AR, Shinomiya N, Kistner E, Kenny H, Becker AR, et al. c-Met overexpression is a prognostic factor in ovarian cancer and an effective target for inhibition of peritoneal dissemination and invasion. Cancer Res. 2007;67(4):1670-9 Epub 2007/02/20.

18. Ghoussoub RA, Dillon DA, D'Aquila T, Rimm EB, Fearon ER, Rimm DL. Expression of c-met is a strong independent prognostic factor in breast carcinoma. Cancer. 1998;82(8):1513-20.

19. Calvo E, Tolcher AW, Hammond LA, Patnaik A, de Bono JS, Eiseman IA, et al. Administration of CI-1033, an irreversible pan-erbB tyrosine kinase inhibitor, is feasible on a 7-day on, 7-day off schedule: a phase I pharmacokinetic and food effect study. Clin Cancer Res. 2004;10(21): 7112-20.
20. Wang Y, Wang SKK, Yang C, Sargeant AM, Hung J, Kashida $\mathrm{Y}$, et al. Targeting endoplasmic reticulum stress and Akt with OSU-03012 and gefitinib or erlotinib to overcome resistance to epidermal growth factor receptor inhibitors. Cancer Res. 2008;68(8):2820-30.

21. Chitcholtan K, Asselin E, Parent S, Sykes P, Evans J. Differences in growth properties of endometrial cancer in three dimensional (3D) culture and 2D cell monolayer. Exp Cell Res. 2013;319(1):75-87.

22. Chitcholtan K, Sykes PH, Evans JJ. The resistance of intracellular mediators to doxorubicin and cisplatin are distinct in $3 \mathrm{D}$ and $2 \mathrm{D}$ endometrial cancer. J Transl Med. 2012;10:38.

23. Lee JM, Mhawech-Fauceglia P, Lee N, Paranian LC, Lin YG, Gayther SA, et al. A three dimensional microenvironment alters protein expression and chemosensitivity of epithelial ovarian cancer cells in vitro. Lab Investig. 2013;93:528-42.

24. Hogg SJ, Chitcholtan K, Hassan W, Sykes PH, Garrill A. Resveratrol, Acetyl-resveratrol, and polydatin exhibit antigrowth activity against $3 \mathrm{D}$ cell aggregates of the SKOV-3 and OVCAR-8 ovarian cancer cell lines. Obstet Gynecol Int. 2016;2015:ID 279591.

25. Lafky JM, Wilken JA, Baron AT, Maihle NJ. Clinical implications of the ErbB/epidermal growth factor (EGF) receptor family and its ligands in ovarian cancer. Biochim Biophys Acta. 2008;1785(2):232-65.

26. Campiglio M, Ali S, Knyazev PG, Ullrich A. Characteristics of EGFR family-mediated HRG signals in human ovarian cancer. J Cell Biochem. 1999;73(4):522-32.

27. Parrott JA, Skinner MK. Expression and action of hepatocyte growth factor in human and bovine normal ovarian surface epithelium and ovarian cancer. Biol Reprod. 2000;62(3):491-500.

28. Loupakis F, Cremolini C, Fioravanti A, Orlandi P, Salvatore L, Masi G, et al. EGFR ligands as pharmacodynamic biomarkers in metastatic colorectal cancer patients treated with cetuximab and irinotecan. Target Oncol. 2014;9(3):205-14.

29. Kwon Y, Smith B, Zhou Y, Kaufman M, Godwin A. Effective inhibition of c-MET-mediated signaling, growth and migration of ovarian cancer cells is influenced by the ovarian tissue microenvironment. Oncogene. 2015;34(2):144-53

30. Jiang HL, Jin JZ, Wu D, Xu D, Lin GF, Yu H, et al. Celastrol exerts synergistic effects with PHA-665752 and inhibits tumor growth of c-Met-deficient 
hepatocellular carcinoma in vivo. Mol Biol Rep. 2013;40(7):4203-9.

31. Kris MG, Natale RB, Herbst RS, Lynch TJ Jr, Prager D, Belani CP, et al. Efficacy of gefitinib, an inhibitor of the epidermal growth factor receptor tyrosine kinase, in symptomatic patients with non-small cell lung cancer: a randomized trial. JAMA. 2003;290(16):2149-58.

32. Schilder RJ, Sill MW, Lee YC, Mannel RA. A phase II trial of erlotinib in recurrent squamous cell carcinoma of the cervix: a gynaecologic oncology group study. Gynaecol Cancer. 2009;19:929-33.

33. Martin SAP, Miller A, Emad L, Rahmani M, Walker T, Mitchell C, et al. Lapatinib resistance in HCT116 cells is mediated by elevated MCL-1 expression and decreased BAK activation and not by ERBB receptor kinase mutation. Mol Pharmacol. 2008;74(3):807-22.

34. Kwak E. The role of irreversible HER family inhibition in the treatment of patients with non small cell lung cancer. Oncologist. 2011;16:1498-507.

35. Niemann C, Brinkmann V, Spitzer E, Hartmann G, Sachs $M$, Naundorf $H$, et al. Reconstitution of mammary gland development in vitro: requirement of c-met and c-erbB2 signaling for branching and alveolar morphogenesis. J Cell Biol. 1998;143(2):533-45.

36. Irwin ME, Nelson LD, Santiago-O'Farrill JM, Knouse PD, Miller CP, Palla SL, et al. Small molecule ErbB inhibitors decrease proliferative signaling and promote apoptosis in philadelphia chromosome-positive acute lymphoblastic leukemia. PLoS One. 2013;8(8):e70608.

37. Spector N, Xia W, El-Hariry I, Yarden Y, Bacus S. HER2 therapy: small molecule HER-2 tyrosine kinase inhibitors. Breast Cancer Res. 2007;9(2):205.

38. Yang Y, Wislez M, Fujimoto N, Prudkin L, Izzo JG, Uno F, et al. A selective small molecule inhibitor of c-Met, PHA-665752, reverses lung premalignancy induced by mutant K-ras. Mol Cancer Ther. 2008;7(4):952-60.

39. Ma PC, Schaefer E, Christensen JG, Salgia R. A selective small molecule c-MET Inhibitor, PHA665752, cooperates with rapamycin. Clin Cancer Res. 2005;11(6):2312-9.
40. Dilworth JT, Wojtkowiak JW, Mathieu P, Tainsky MA, Reiners JJ Jr, Mattingly RR, et al. Suppression of proliferation of two independent NF1 malignant peripheral nerve sheath tumor cell lines by the pan-ErbB inhibitor CI-1033. Cancer Biol Ther. 2008;7(12):1938-46.

41. Crosswell HE, Dasgupta A, Alvarado CS, Watt T, Christensen JG, De $P$, et al. PHA665752, a small-molecule inhibitor of c-Met, inhibits hepatocyte growth factor-stimulated migration and proliferation of c-Met-positive neuroblastoma cells. BMC Cancer. 2009;9:411.

42. Tang Z, Du R, Jiang S, Wu C, Barkauskas DS, Richey $J$, et al. Dual MET-EGFR combinatorial inhibition against T790M-EGFR-mediated erlotinib-resistant lung cancer. Br J Cancer. 2008;99(6):911-22.

43. Konner J, Schilder RJ, DeRosa FA, Gerst SR, Tew WP, Sabbatini PJ, et al. A phase II study of cetuximab/paclitaxel/carboplatin for the initial treatment of advanced-stage ovarian, primary peritoneal, or fallopian tube cancer. Gynecol Oncol. 2008;110:140-5.

44. Weroha SJ, Oberg AL, Ziegler KLA, Dakhilm SR, Rowland KM, Hartmann LC, et al. Phase II trial of lapatinib and topotecan (LapTop) in patients with platinum-refractory/resistant ovarian and primary peritoneal carcinoma. Gynecol Oncol. 2011;122(1):116-20.

45. Chun PY, Feng FY, Scheurer AM, Davis MA, Lawrence TS, Nyati MK. Synergistic effects of gemcitabine and gefitinib in the treatment of head and neck carcinoma. Cancer Res. 2006;66(2):981-8.

46. Cho WC, Roukos DH. Trastuzumab emtansine for advanced HER2-positive breast cancer and beyond: genome landscape-based targets. Expert Rev Anticancer Ther. 2013;13(1):5-8.

47. Pivot X, Manikhas A, Żurawski B, Chmielowska E, Karaszewska B, Allerton $\mathrm{R}$, et al. CEREBEL (EGF111438): a phase III, randomized, open-label study of lapatinib plus capecitabine versus trastuzumab plus capecitabine in patients with human epidermal growth factor receptor 2-positive metastatic breast cancer. J Clin Oncol. 2015;33:1564-73. 